\title{
Pemanfaatan Limbah Cangkang Kerang Hijau (Perna Viridis) Menjadi Kitin Sebagai Biokoagulan Air Sungai
}

\author{
Syamsidar $\mathrm{HS}^{1}$, Ramayana ${ }^{2}$, Kurnia Ramadani ${ }^{2}$ \\ ${ }^{1}$ Sekolah Tinggi Agama Islam Negeri Watampone \\ ${ }^{2}$ Jurusan Kimia, Fakultas Sains dan Teknologi, Universitas Islam Negeri Alauddin \\ Makassar \\ E-mail : syamsidar_hs@yahoo,com
}

\begin{abstract}
This study aims to determine the optimum weight of chitin that used as biocoagulant of river water. The water sample is taken from Kajenjeng river and the chitin used for research are isolated from green mussels (Perna viridis) shell powder through three steps such as deproteination by $\mathrm{NaOH} \mathrm{3 \% ,} \mathrm{demineralization} \mathrm{by} \mathrm{HCl} 1,25 \mathrm{~N}$ and depigmentation by $\mathrm{NaOCl} 4 \%$. Then, the obtained chitin are contacted into water with variation of 0,25 gram; 0,5 gram; 0,75 gram and 1 gram in an hour. The result showed that optimum weight of chitin for COD determination, total hardness, calcium and turbidity is 0,75 gram, while optimum weight of chitin for magnesium determination is 0,5 gram.
\end{abstract}

Keywords: green mussels shell, chitin, water biocoagulant

\section{PENDAHULUAN}

Air merupakan suatu zat yang mengandung mineral dan zat-zat makanan yang dibutuhkan oleh makhluk hidup. Jadi, manusia, hewan dan tumbuh-tumbuhan tidak bisa bertahan hidup tanpa adanya air. Air yang digunakan dalam kehidupan sehari-hari harus memenuhi syarat dari segi kualitas maupun kuantitasnya. Seiring dengan perkembangan zaman, populasi manusia semakin meningkat, padatnya pemukiman dan pesatnya pembangunan industri mengakibatkan kualitas air bersih mengalami penurunan.

Penggunaan koagulan sintetik untuk penjernih air sudah umum dilakukan dalam kehidupan sehari-hari misalnya penggunaan tawas $\left(\mathrm{Al}_{2}\left(\mathrm{SO}_{4}\right)_{3}\right)$, besi (III) klorida hidrat $\left(\mathrm{FeCl}_{3} \cdot 6 \mathrm{H}_{2} \mathrm{O}\right)$, besi (II) sulfat hidrat $\left(\mathrm{FeSO}_{4} \cdot 7 \mathrm{H}_{2} \mathrm{O}\right)$ dan poli aluminium klorida (PAC). Meskipun koagulan tersebut lebih praktis dalam penggunaannya dan mudah diperoleh, akan tetapi penggunaan koagulan sintetik tersebut mempunyai kelemahan, seperti bertambahnya jumlah ion-ion $\mathrm{Al}^{3+}, \mathrm{Fe}^{3+}$, ion klor di dalam air dan koagulan tersebut tidak mudah terbiodegradasi. Oleh karena itu, diperlukan adanya penelitian tentang pemanfaatan koagulan alam yang bersifat lebih ramah lingkungan, dapat diperbaharui dan mudah terbiodegradasi (Manurung, 2011).

Kitin merupakan biopolimer golongan polisakarida yang memiliki gugus aktif yaitu gugus $\mathrm{NHCOCH}_{3}$ yang berada pada ikatan karbon kedua dan gugus $\mathrm{OH}$ yang berada pada ikatan 
karbon ketiga dan keenam (Asto, 2015). Menurut Anonymous dalam Erryana Martati, dkk (2012) kitin dalam bidang industri dapat diaplikasikan untuk mengikat bahan pencemar baik bahan organik maupun anorganik. Menurut Sandford dalam Erryana Martati, dkk (2012) kelebihan penggunaan kitin yaitu tidak beracun, dapat terdegradasi oleh mikroorganisme dan ramah lingkungan. Kitin dapat digunakan sebagai pengkelat ion logam dan dapat berperan sebagai flokulan. Oleh karena itu, pada penelitian ini akan dipelajari potensi dan efektivitas kitin dari cangkang kerang hijau sebagai biokoagulan air sungai.

\section{METODE PENELITIAN}

Alat

Alat-alat yang digunakan pada penelitian ini yaitu Fourier Transform Infrared (FTIR), turbidimeter, oven, ayakan 40 mesh, shaker water bath, magnetik stirrer, neraca analitik, hot plate, blender dan alat-alat gelas laboratorium.

\section{Bahan}

Bahan-bahan yang digunakan dalam penelitian ini yaitu asam klorida $(\mathrm{HCl})$, asam oksalat $\left(\mathrm{H}_{2} \mathrm{C}_{2} \mathrm{O}_{4}\right)$, asam sulfat $\left(\mathrm{H}_{2} \mathrm{SO}_{4}\right)$, aquades $\left(\mathrm{H}_{2} \mathrm{O}\right)$, buffer $\mathrm{pH} 10$, cangkang kerang hijau, indikator eriochrome black T (EBT), indikator mureksid, kalium permanganat $\left(\mathrm{KMnO}_{4}\right)$, kertas saring, natrium etilen diamin tetraasetat $\left(\mathrm{Na}_{2} \mathrm{EDTA}\right)$, natrium hidroksida $(\mathrm{NaOH})$, natrium hipoklorit $(\mathrm{NaOCl}) 4 \%$.

\section{Prosedur Kerja}

\section{Isolasi Kitin dari Cangkang Kerang Hijau}

Cangkang kerang hijau dicuci dengan air mengalir untuk menghilangkan kotoran yang melekat, kemudian dikeringkan dalam oven pada suhu $80^{\circ} \mathrm{C}$ sampai kering. Setelah itu cangkang kerang hijau yang telah kering dihaluskan sampai berukuran 40 mesh.

a. Deproteinasi (Penghilangan Protein)

Cangkang kerang hijau dideproteinasi menggunakan larutan $\mathrm{NaOH} 3 \%$ dengan perbandingan 1:6 (b/v) sambil diaduk dan dipanaskan pada suhu $80^{\circ} \mathrm{C}-85^{\circ} \mathrm{C}$ selama $1 \mathrm{jam}$. Setelah itu dipisahkan dari larutannya, padatan dicuci dengan aquades hingga netral. Kemudian dikeringkan pada suhu $80^{\circ} \mathrm{C}$ sampai kering.

b. Demineralisasi (Penghilangan Mineral)

Padatan kering hasil deproteinasi selanjutnya didemineralisasi dengan menggunakan larutan $\mathrm{HCl} 1,25 \mathrm{~N}$ dengan perbandingan $1: 10(\mathrm{~b} / \mathrm{v})$ dan diaduk pada suhu $70^{\circ} \mathrm{C}-75^{\circ} \mathrm{C}$ selama 1 jam. Setelah disaring, padatan dicuci dengan aquades hingga netral kemudian dikeringkan pada suhu $80^{\circ} \mathrm{C}$ dalam oven untuk mendapatkan kitin kering.

c. Depigmentasi (Penghilangan Warna)

Hasil demineralisasi kemudian didepigmentasi dengan menggunakan larutan natrium hipoklorit $(\mathrm{NaOCl}) 4 \%$ dengan perbandingan 1:10 (b/v) dan diaduk pada suhu $80^{\circ} \mathrm{C}$ selama 1 
jam. Kemudian, larutan dicuci dengan menggunakan aquades hingga netral. Kemudian disaring dan endapan kitin dikeringkan dalam oven pada suhu $80^{\circ} \mathrm{C}$ sampai kering.

\section{Pengujian COD, Kesadahan Total, Kalsium (Ca), Magnesium (Mg), dan Kekeruhan pada Air Sungai}

a. COD (Chemical Oxigen Demand)

Sampel air sungai sebanyak $50 \mathrm{~mL}$ dimasukkan ke dalam erlenmeyer. Ditambahkan $\mathrm{H}_{2} \mathrm{SO}_{4}$ $4 \mathrm{~N}$ sebanyak 2,5 $\mathrm{mL}$ dan ditambahkan $\mathrm{KMnO}_{4}$ 0,05 N sebanyak $5 \mathrm{~mL}$. Kemudian dipanaskan hingga mendidih dan ditambahkan $\mathrm{H}_{2} \mathrm{C}_{2} \mathrm{O}_{4}$ sebanyak $5 \mathrm{~mL}$ lalu dititrasi dengan $\mathrm{KMnO}_{4} 0,05 \mathrm{~N}$. Dicatat volume $\mathrm{KMnO}_{4}$ yang digunakan setelah terjadi perubahan warna dari tak berwarna menjadi merah muda. Dilakukan analisis sebanyak dua kali.

\section{b. Kesadahan Total}

Sampel air sungai sebanyak $25 \mathrm{~mL}$ dimasukkan ke dalam erlenmeyer. Ditambahkan $2 \mathrm{~mL}$ larutan buffer $\mathrm{pH} 10 \pm 0,1$. Kemudian ditambahkan seujung spatula $30 \mathrm{mg}$ sampai dengan $50 \mathrm{mg}$ indikator EBT lalu dititrasi dengan larutan baku $\mathrm{Na}_{2}$ EDTA 0,01 M secara perlahan sampai terjadi perubahan warna merah keunguan menjadi biru dan dicatat volume $\mathrm{Na}_{2}$ EDTA yang digunakan. Dilakukan analisis sebanyak dua kali.

c. Kalsium (Ca)

Sampel air sungai sebanyak $25 \mathrm{~mL}$ dimasukkan ke dalam erlenmeyer. Ditambahkan $2 \mathrm{~mL}$ larutan $\mathrm{NaOH} 1 \mathrm{~N}$ sampai dicapai $\mathrm{pH} 12$ sampai dengan 13. Kemudian ditambahkan seujung spatula $30 \mathrm{mg}$ sampai dengan $50 \mathrm{mg}$ indikator mureksid lalu dititrasi dengan larutan baku $\mathrm{Na}_{2}$ EDTA 0,01 M secara perlahan sampai terjadi perubahan warna merah muda menjadi ungu dan dicatat volume $\mathrm{Na}_{2}$ EDTA yang digunakan. Dilakukan analisis sebanyak dua kali. Kadar magnesium $(\mathrm{Mg})$ dapat diketahui dengan cara mengurangkan volume titrasi penentuan kesadahan total dengan volume titrasi penentuan kadar kalsium $(\mathrm{Ca})$.

\section{d. Kekeruhan (Turbidity)}

Metode pengukuran yang dilakukan adalah metode Nefelometrik (Unit Kekeruhan NTU).

Diulangi pengujian di atas setelah penambahan kitin dengan massa 0,25 gram, 0,5 gram, 0,75 gram dan 1 gram dalam $100 \mathrm{~mL}$ air sungai dengan waktu kontak selama 1 jam yang diaduk dengan kecepatan $100 \mathrm{rpm}$.

\section{HASIL DAN PEMBAHASAN \\ Hasil Isolasi Kitin Cangkang Kerang Hijau}

Isolasi kitin dari cangkang kerang hijau (Perna viridis) dilakukan melalui tiga tahap isolasi yaitu deproteinasi (penghilangan protein) dengan menggunakan larutan natrium hidroksida $(\mathrm{NaOH}) 3 \%$, demineralisasi (penghilangan mineral) dengan menggunakan asam klorida $(\mathrm{HCl})$ $1,25 \mathrm{~N}$ dan depigmentasi (penghilangan warna) dengan menggunakan natrium hipoklorit $(\mathrm{NaOCl}) 4 \%$. Hasil isolasi kitin kemudian dianalisa secara kuantitatif dengan menggunakan FTIR. 
Deproteinasi merupakan proses penghilangan protein pada serbuk cangkang kerang hijau dengan menggunakan basa kuat. Protein dalam cangkang berikatan secara kovalen dengan kitin tetapi terdapat juga protein yang berikatan secara fisik yaitu protein dari sisa-sisa daging yang menempel pada matriks cangkang yang jumlahnya bervariasi. Proses ini dilakukan dengan perlakuan menggunakan larutan $\mathrm{NaOH} 3 \%$. Protein dalam serbuk cangkang bereaksi dengan $\mathrm{NaOH}$ sehingga protein akan terlepas dan membentuk natrium proteinat yang larut (Martati, dkk, 2012). Reaksi penghilangan protein dengan menggunakan $\mathrm{NaOH}$ dapat dilihat pada gambar berikut ini:
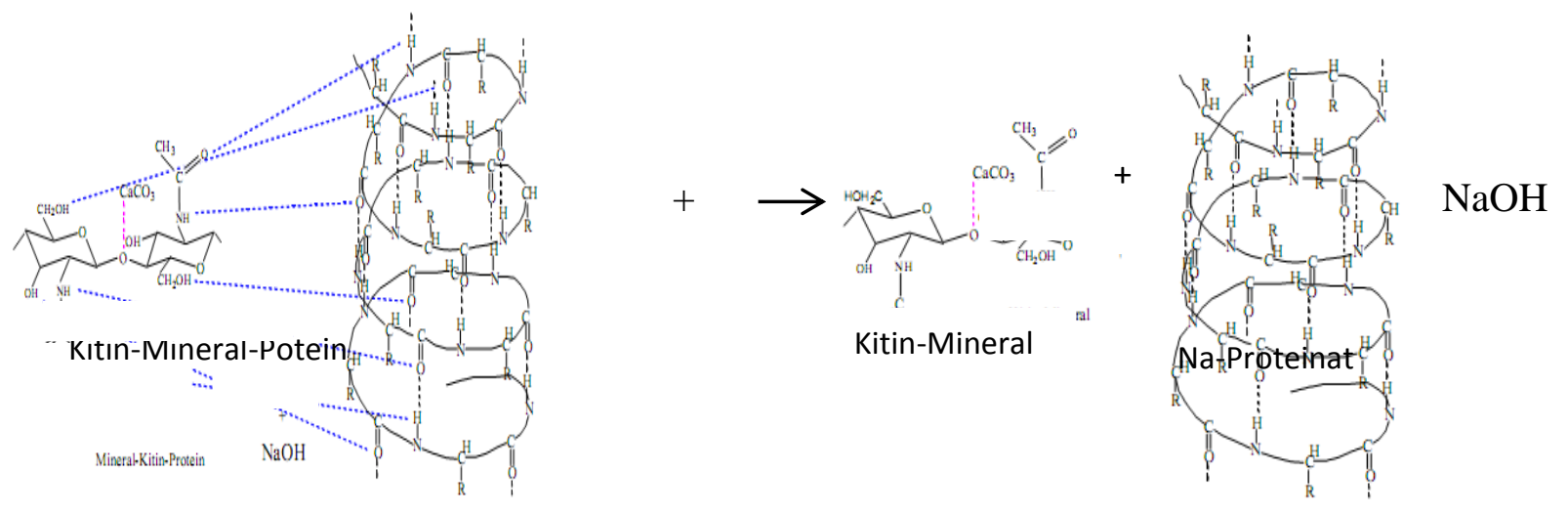

Gambar 1. Reaksi Deproteinasi (Sumber: Rifai, 2010)

Demineralasasi merupakan proses penghilangan mineral pada serbuk cangkang kerang hijau dengan menggunakan asam kuat. Menurut Oktarina Sumandari (2012) cangkang kerang hijau mengandung mineral 33,56\% kalsium yang berbentuk senyawa berupa $\mathrm{CaCO}_{3}$. Kandungan mineral tersebut dapat dihilangkan dengan menggunakan $\mathrm{HCl}$.

Reaksi antara $\mathrm{CaCO}_{3}$ dengan $\mathrm{HCl}$ menyebabkan terjadinya pembentukan gas $\mathrm{CO}_{2}$ yang ditandai dengan adanya gelembung-gelembung udara pada saat penambahan $\mathrm{HCl}$ ke dalam sampel. Menurut Johnson dan Peniston dalam Arif (2013) bahwa demineralisasi secara umum dilakukan dengan larutan $\mathrm{HCl}$ atau asam lain seperti $\mathrm{H}_{2} \mathrm{SO}_{4}$ pada kondisi tertentu. Akan tetapi, keefektifan $\mathrm{HCl}$ dalam melarutkan kalsium $10 \%$ lebih tinggi daripada $\mathrm{H}_{2} \mathrm{SO}_{4}$.

Depigmentasi merupakan proses penghilangan warna pada kitin dengan menggunakan oksidator atau pelarut organik. Hasil dari tahap deproteinasi dan demineralisasi tersebut telah diperoleh kitin yang berwarna coklat. Proses depigmentasi dilakukan dengan menggunakan larutan $\mathrm{NaOCl} 4 \%$ Selain sebagai pemutih kitin, proses ini juga berfungsi sebagai pembersih dari zat-zat pengotor yang ada pada saat proses deproteinasi dan demineralisasi sehingga membuat kitin memiliki kemampuan yang lebih baik dalam proses biokoagulan.

Struktur kitin terdiri dari beberapa gugus fungsi yang dapat diidentifikasi dengan menggunakan FTIR. Gugus fungsi yang terdapat dalam struktur kitin diantaranya yaitu - $\mathrm{OH},-$ $\mathrm{NH},-\mathrm{C}-\mathrm{H},-\mathrm{C}=\mathrm{O},-\mathrm{C}-\mathrm{OH},-\mathrm{C}-\mathrm{O}$ dan $-\mathrm{C}-\mathrm{N}$. Gambar berikut ini menyajikan hasil identifikasi kitin dengan menggunakan FTIR. 


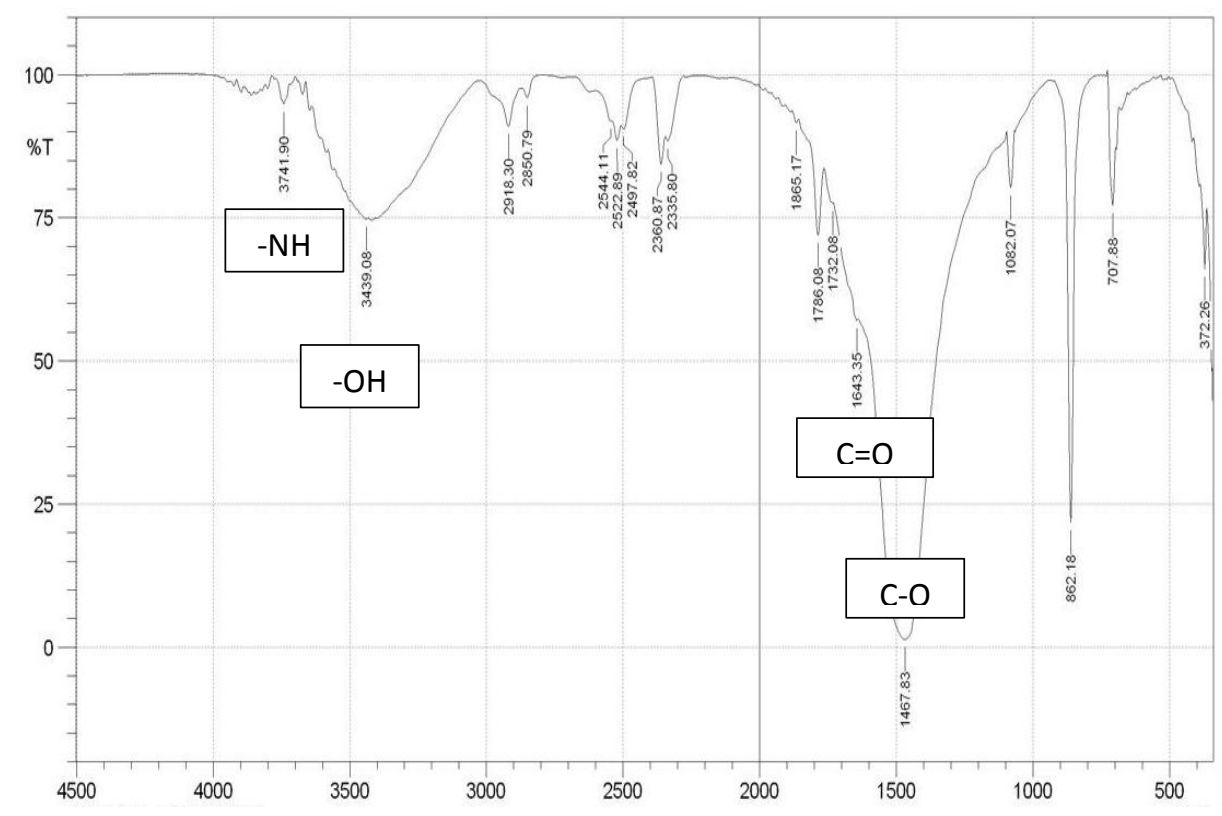

Gambar 2 Spektrum FTIR Kitin Hasil Isolasi dari Cangkang Kerang Hijau

\section{Aplikasi Kitin sebagai Biokogulan Air Sungai}

Kadar COD pada air sungai sebelum penambahan kitin memiliki kadar COD sebesar 34,76 mg/L. Berdasarkan Tabel 1, kadar COD pada air sungai mengalami penurunan seiring dengan besarnya dosis kitin yang ditambahkan ke dalam sampel air sungai, dapat dikatakan bahwa semakin banyak dosis kitin yang ditambahkan pada sampel air sungai penurunan kadar COD juga akan semakin besar. Akan tetapi pada penambahan kitin sebanyak 1 gram mengalami peningkatan kadar COD sehingga dapat disimpulkan bahwa berat optimum kitin untuk menurunkan kadar COD dalam sampel air sungai yaitu sebesar 0,75 gram dengan kadar COD sebesar 11,06 mg/L, untuk mengetahui lebih jelasnya penurunan kadar COD pada sampel air sungai setelah penambahan kitin dapat dilihat pada Gambar 3.

Tabel 1. Hasil Uji COD pada Sampel Air Sungai

\begin{tabular}{|c|c|c|}
\hline o. & $\begin{array}{l}\text { Berat Kitin } \\
\quad \text { (gram) }\end{array}$ & $\begin{array}{c}\text { Kadar COD } \\
(\mathrm{mg} / \mathrm{L})\end{array}$ \\
\hline
\end{tabular}




\begin{tabular}{lcc}
\hline 1 & 0 & 34,76 \\
2 & 0,25 & 18,96 \\
$\vdots$ & 0,5 & 15,80 \\
$<$ & 0,75 & 11,06 \\
$\vdots$ & 1 & 18,96 \\
\hline
\end{tabular}

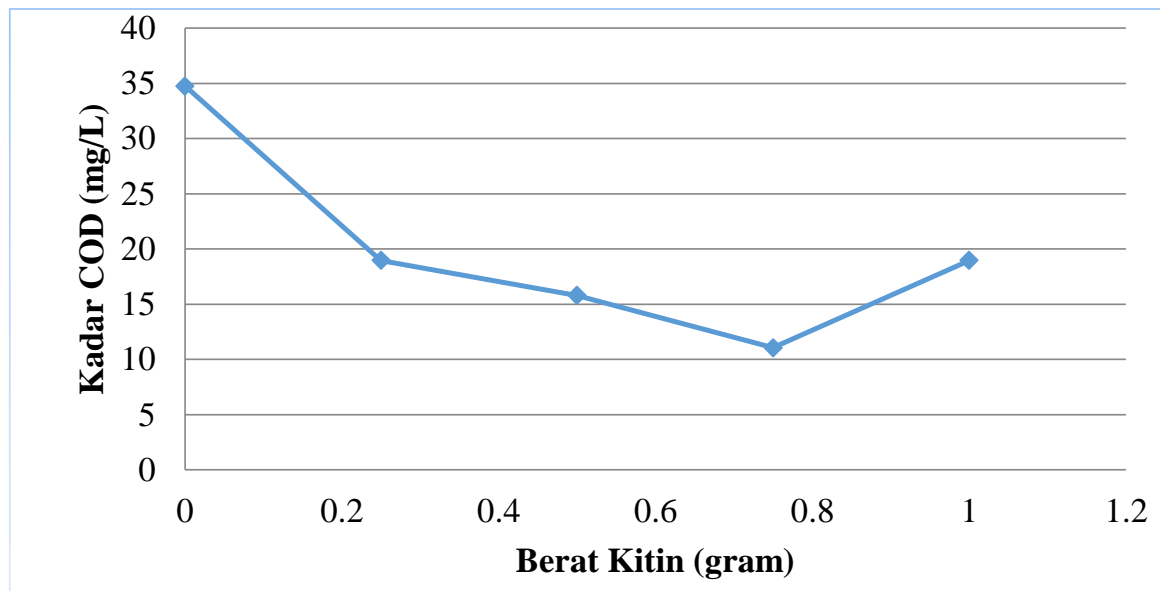

\section{Gambar 3. Grafik Hasil Uji COD pada Air Sungai setelah Penambahan Kitin}

Kadar kesadahan pada air sungai sebelum penambahan kitin memiliki kadar kesadahan sebesar $60 \mathrm{mg} / \mathrm{L}$. Berdasarkan Tabel 2, kadar kesadahan pada air sungai mengalami penurunan pada penambahan kitin sebanyak 0,25 gram dengan kadar kesadahan sebesar $58 \mathrm{mg} / \mathrm{L}$ dan pada penambahan kitin sebanyak 0,75 gram dengan kadar sebesar $56 \mathrm{mg} / \mathrm{L}$. Akan tetapi pada penambahan kitin sebanyak 0,5 gram dan 1 gram pada sampel air sungai tidak menurunkan kesadahan pada air sungai, untuk mengetahui lebih jelasnya dapat dilihat pada Gambar 4.

Tabel 2. Hasil Uji Kesadahan Total $\left(\mathrm{CaCO}_{3}\right)$ pada Sampel Air Sungai

\begin{tabular}{ccc}
\hline ] & $\begin{array}{c}\text { Berat Kitin } \\
(\text { gram })\end{array}$ & $\begin{array}{c}\text { Kesadahan Total } \\
(\mathrm{mg} / \mathrm{L})\end{array}$ \\
\hline$\vdots$ & 0 & 60 \\
$\vdots$ & 0,25 & 58 \\
$\vdots$ & 0,5 & 60 \\
$\vdots$ & 0,75 & 56 \\
\hline
\end{tabular}




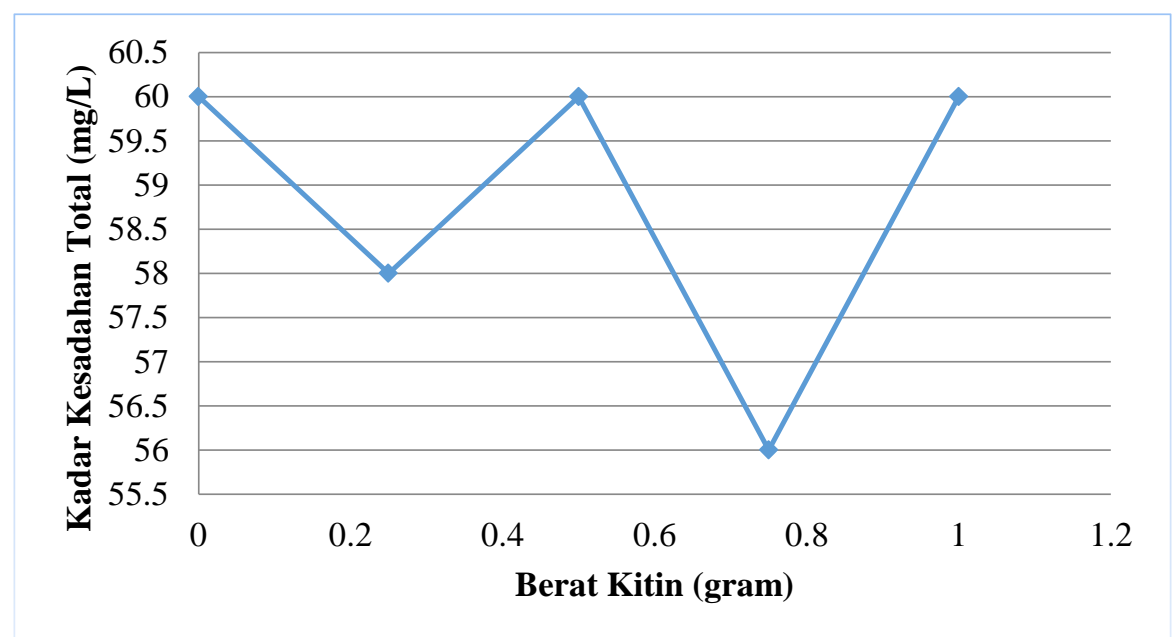

Gambar 4. Grafik Hasil Uji Kesadahan pada Air Sungai setelah Penambahan Kitin

\begin{tabular}{ccc}
\multicolumn{2}{c}{ Tabel 3. Hasil Uji Kalsium (Ca) pada Sampel Air Sungai } \\
\hline \multirow{2}{*}{$\begin{array}{c}\text { Berat Kitin } \\
(\text { gram })\end{array}$} & $\begin{array}{c}\text { Kadar Kalsium }(\mathrm{Ca}) \\
(\mathrm{mg} / \mathrm{L})\end{array}$ \\
\hline & 0 & 16 \\
$\vdots$ & 0,25 & 16 \\
$\vdots$ & 0,5 & 18,4 \\
$\vdots$ & 0,75 & 15,2 \\
\hline
\end{tabular}

Kadar kalsium pada air sungai sebelum penambahan kitin memiliki kadar kalsium sebesar $16 \mathrm{mg} / \mathrm{L}$. Berdasarkan Tabel 3 kadar kalsium pada air sungai mengalami penurunan pada penambahan kitin sebanyak 0,75 gram dengan kadar kesadahan sebesar 15,2 mg/L. Akan tetapi pada penambahan kitin sebanyak 0,25 gram dan 1 gram pada sampel air sungai tidak menurunkan kalsium pada air sungai, bahkan pada penambahan kitin sebanyak 0,5 gram mengalami kenaikan yang kadarnya lebih besar dari kadar kalsium pada air sungai sebelum penambahan kitin yaitu sebesar 18,4 mg/L. 


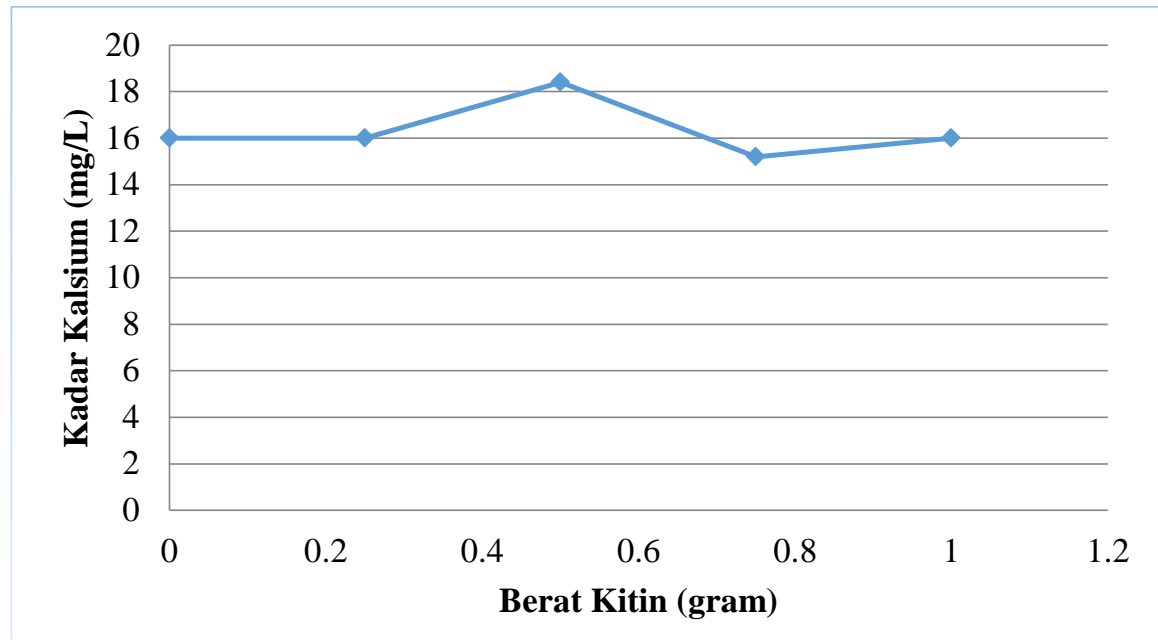

Gambar 5. Grafik Hasil Uji Kalsium pada Air Sungai setelah Penambahan Kitin

Kadar magnesium pada air sungai diperoleh dari pengurangan volume $\mathrm{Na}_{2}$ EDTA hasil uji kesadahan total dengan volume $\mathrm{Na}_{2}$ EDTA hasil uji kalsium. Kadar magnesium pada air sungai sebelum penambahan kitin sebesar 4,860 mg/L. Berdasarkan Tabel 4 kadar magnesium pada air sungai mengalami penurunan seiring dengan seiring dengan besarnya dosis kitin yang ditambahkan ke dalam sampel air sungai. Akan tetapi pada penambahan kitin sebanyak 0,75 gram dan 1 gram mengalami peningkatan kadar kalsium dalam air sungai untuk mengetahui lebih jelasnya dapat dilihat pada Gambar 6.

Tabel 4 Hasil Uji Magnesium (Mg) pada Sampel Air Sungai

\begin{tabular}{ccc}
\hline No. & $\begin{array}{c}\text { Berat Kitin } \\
(\text { gram })\end{array}$ & $\begin{array}{c}\text { Kadar Magnesium }(\mathrm{Mg}) \\
(\mathrm{mg} / \mathrm{L})\end{array}$ \\
\hline 1 & 0 & 4,860 \\
2 & 0,25 & 4,374 \\
3 & 0,5 & 3,402 \\
4 & 0,75 & 4,374 \\
5 & 1 & 4,860 \\
\hline
\end{tabular}

Kadar magnesium pada air sungai diperoleh dari pengurangan volume $\mathrm{Na}_{2}$ EDTA hasil uji kesadahan total dengan volume $\mathrm{Na}_{2}$ EDTA hasil uji kalsium. Kadar magnesium pada air sungai sebelum penambahan kitin sebesar 4,860 mg/L. Berdasarkan Tabel 4 kadar magnesium pada air sungai mengalami penurunan seiring dengan seiring dengan besarnya dosis kitin yang ditambahkan ke dalam sampel air sungai. Akan tetapi pada penambahan kitin sebanyak 0,75 gram dan 1 gram mengalami peningkatan kadar kalsium dalam air sungai untuk mengetahui lebih jelasnya dapat dilihat pada Gambar 6. 


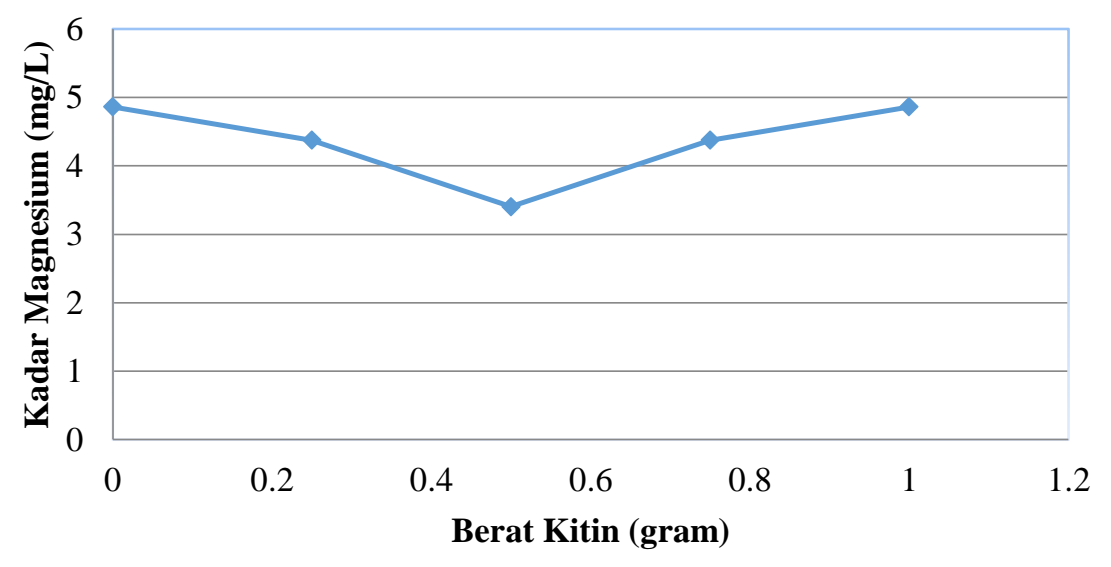

Gambar 6. Grafik Hasil Uji Magnesium pada Air Sungai setelah Penambahan Kitin

Kadar kekeruhan pada air sungai sebelum penambahan kitin sebesar 68,3 NTU. Berdasarkan Table 5,kekeruhan pada air sungai mengalami penurunan seiring dengan besarnya dosis kitin yang ditambahkan ke dalam sampel air sungai, Akan tetapi pada penambahan kitin sebanyak 1 gram mengalami peningkatan kekeruhan sebesar 45,4 NTU sehingga dapat disimpulkan bahwa berat optimum kitin untuk menurunkan kekeruhan dalam sampel air sungai yaitu sebesar 0,75 gram dengan kekeruhan sebesar 40,75 NTU, untuk mengetahui lebih jelasnya penurunan kekeruhan pada sampel air sungai setelah penambahan kitin dapat dilihat pada Gambar 7.

Tabel 5. Hasil Uji Kekeruhan pada Sampel Air Sungai

\begin{tabular}{|c|c|c|c|c|}
\hline \multirow[t]{2}{*}{ No. } & \multirow{2}{*}{$\begin{array}{l}\text { Berat Kitin } \\
\text { (gram) }\end{array}$} & \multicolumn{3}{|c|}{ Hasil (NTU) } \\
\hline & & $\mathrm{I}$ & II & Rata-Rata \\
\hline 1 & 0 & 68,5 & 68,1 & 68,3 \\
\hline 2 & 0,25 & 50,8 & 50,2 & 50,5 \\
\hline 3 & 0,5 & 43,7 & 46,7 & 45,2 \\
\hline 4 & 0,75 & 40,5 & 41,0 & 40,75 \\
\hline 5 & 1 & 42,0 & 48,8 & 45,4 \\
\hline
\end{tabular}




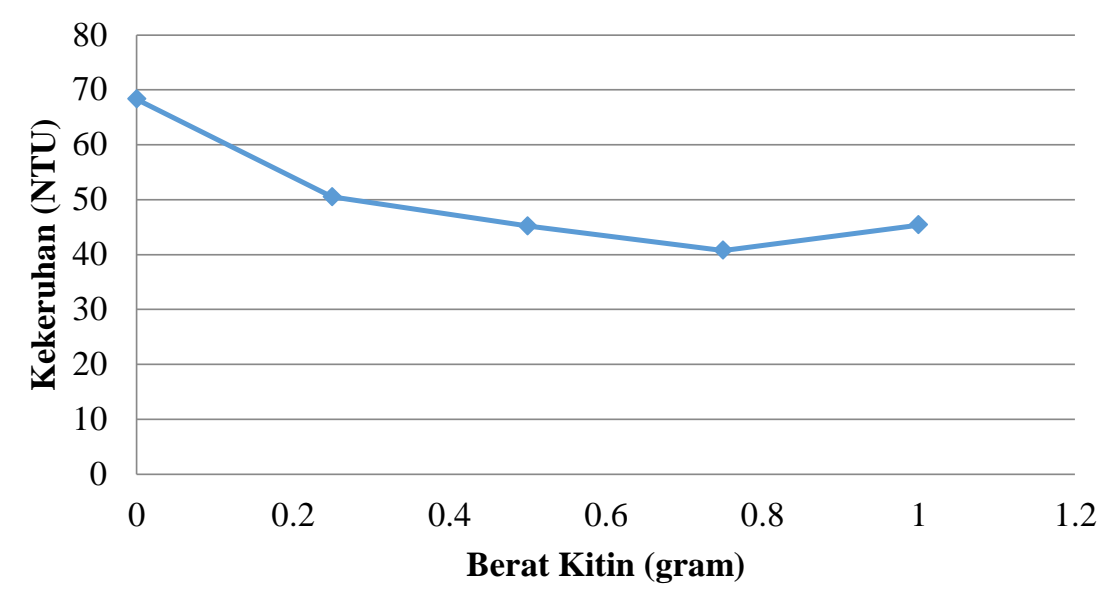

Gambar 7. Grafik Hasil Uji Kekeruhan pada Air Sungai setelah Penambahan Kitin

\section{PENUTUP \\ Kesimpulan}

1. Berat optimum kitin untuk menurunkan kadar COD, kesadahan total, kalsium dan kekeruhan adalah 0,75 gram, sedangkan berat optimum untuk menurunkan kadar magnesium adalah 0,5 gram pada $100 \mathrm{~mL}$ sampel air sungai.

2. Kadar COD, kesadahan total, kalsium dan magnesium sampel air sungai setelah penambahan kitin memenuhi standar baku mutu air sungai kecuali kadar kekeruhan.

\section{DAFTAR PUSTAKA}

Arif, A. R., dkk. 2013, Isolasi Kitin dari Limbah Udang Putih (Penaeus merguiensis) Secara Enzimatis. Seminar Nasional Kimia Peran Sain dan Teknologi Dalam Mendukung Ketahanan Pangan dan Energi Nasional.

Asto, E. S., dkk. 2015, Pengaruh pH dan Lama Kontak pada Adsorpsi Ion Logam $\mathrm{Cu}^{2+}$ Menggunakan Kitin Terikat Silang Glutaraldehid. Kimia Student Journal, 1(1): 647-653.

Manurung, M., 2011, Potensi Kitin/Kitosan dari Kulit Udang sebagai Biokoagulan Penjernih Air. Jurnal Kimia 3(2):182-188.

Martati, E., dkk. 2012, Isolasi dari Cangkang Rajungan (Portunus pelagicus) Kajian Suhu dan Waktu Proses Deproteinasi. J. Tek. Pert. 3(2): 129-137.

Rifai, D. N. R.., 2010, Isolasi dan Pemanfaatan Kitin, Kitosan dari Cangkang Hewan Mimi (Horseshoe crab) Menggunakan Spektrofotometer Infra Merah”. Alchemy 2(1): 104-157. 
Sumandari, O., 2012. Pengaruh Penambahan Tepung Cangkang Kerang Hijau pada Medium Pertumbuhan terhadap Kemampuan Metarhizium majus UICC 295 Menginfeksi Larva Oryctes rhinoceros Linnaeus. Skripsi. Departemen Biologi FMIPA Universitas Indonesia. 